\title{
The Effect of Compensation and Supervisor Support Mediated by Job Satisfaction on Employee Retention (Case Study at PT Pradu)
}

\author{
Hery Winoto $\left.\mathbf{T j}^{1}\right)$ \\ hery.winoto@ukrida.ac.id \\ Melitina Tecoalu2) \\ melitina@ukrida.ac.id \\ Shierli Wijaya ${ }^{\left.3^{*}\right)}$ \\ shierliwijaya@gmail.com \\ 1)2)3) Krida Wacana Christian University, Jakarta \\ *) Corresponding Author: shierliwijaya@gmail.com
}

\begin{abstract}
The purpose of this study is to analyze whether the compensation and supervisor support variables mediated by job satisfaction affect employee retention at PT Pradu. The population in this study were 55 employees of the non-academic division. The sampling technique used in this study was total sampling, namely the sampling technique where the number was the same as the population. The type of data used in this study uses primary data which is done by distributing questionnaires directly to Pradu employees. The research data analysis technique used structural equation modeling (SEM) with the Smart PLS (Partial Least Square) version 3.2.7 program.

The results of data analysis found that the R-square of the compensation and supervisor support variables in explaining the job satisfaction variable was 0.701 or about $70 \%$ and $30 \%$ was explained by other factors outside of this study. While the compensation variable, supervisor support, and job satisfaction in explaining the employee retention variable amounted to 0.325 or about $32.5 \%$ and $67.5 \%$ was explained by other factors outside of this study. A total of 5 hypotheses were accepted and 2 hypotheses were rejected after testing with the limit of t-statistics $>$ t-table 1.96 and PValue $<0.05$. It can be concluded that H1: compensation affects job satisfaction, thus the hypothesis is accepted. H2: supervisor support affects job satisfaction, thus the hypothesis is accepted. H3: job satisfaction affects employee retention, thus the hypothesis is accepted. H4: Compensation does not affects employee retention, thus the hypothesis is rejected. H5: Supervisor support does not affects employee retention, thus the hypothesis is rejected. H6: job satisfaction is able to mediate the effect of compensation on employee retention, thus the hypothesis is accepted. H7: Job satisfaction is able to mediate the effect of supervisors support on employee retention, thus the hypothesis is accepted.
\end{abstract}

Keywords: compensation, supervisor support, job satisfaction, employee retention. 


\section{PRELIMINARY}

High performing human resources are one of the important factors that lead to the success of a company. However, efforts to retain the "best employees" are often a main problem, because company leaders have not found the right way to create programs to build a culture of retention in the team or division they lead. In addition, if a company has only a few employees who are competent in their work, retaining the best employees is an important strategy to do.

There are so many factors that cause employees stay for long term in a company or organization. The problem that occurs is the low retention rate of employees at PT Pradu which can be seen through the employee's period of employment is less than 2 years. Employee retention should be considered good if the period of employment is more than 2 years. This can be seen from the employee's data in 2018-2020, the number of employees who resigned was quite a lot and their period of employment was less than 2 years. In 2018 there were 16 people resigned from the total of 34 employees (47\%), in 2019 there were 18 people resigned from the total of 48 employees $(37.5 \%)$, and then in 2020 there were 15 people of the total 55 employees resigned from the company $(27 \%)$.

Generally, one of the factors that can affect employee retention is compensation. The definition of compensation according to Mudayen (2010) is all reward that received by the employee for services or results of work in an organization or company where the compensation can be in the form of money or goods, either directly or indirectly in effort to achieve organizational goals. Providing compensation to the employees can also motivate and provide job satisfaction.

Another factor that is also important in determining whether an employee will stay for a long time in the company is supervisor support. A good supervisor is a leader who is willing to listen the opinions of his subordinates, can establish good communication with subordinates in work or outside work, and can increase employee retention. In addition, good supervisor also try to understand the difficulties experienced by the employees they lead and can provide solutions, and give recognition to employee performance is a powerful way to cultivate their loyalty.

From the discussion above then in this study we want to know whether the compensation factor and also supervisor support have an effect on employee retention at PT Pradu, and the research has never been done before. In addition this study also want to find out the mediating effect of job satisfaction on the relationship between compensation and supervisor support to employee retention. Job satisfaction according to Badriyah (2015) is the attitude or feelings of employees towards pleasant or unpleasant aspects of work in according to assessment of each employee. One of the ways to increase employee retention is that companies must be able to make their employees have a good job satisfaction.

\section{LITERATURE REVIEW \\ Compensation}

Compensation can be defined as everything that an employee gets from the company in return for services that have been done. This can be an effective way for the Human Resources Department to increase work performance, motivation and job 
satisfaction for employees. According to Handaru (2013), compensation is a form of appreciation that a company gives to employees for what employees give to their organization. This compensation is the main reason for employees to join a company.

There are 3 types of employee compensation that can be provided by the company. These types of compensation are:

1. Direct financial compensation, in the form of salary or basic wage payments, incentive payments (which include bonuses, commissions, profit sharing or company stock options), and special payments such as savings programs or share purchase annuities.

2. Indirect financial compensation, in the form of protection programs for employees such as health insurance, labor insurance, life insurance, payments outside of working hours (holidays, annual leave and maternity leave) and also benefits facilities such as vehicles, special parking lots, and private office spaces.

3. Compensation that is non-financial, for example in the form of an attractive job, full of challenges, responsibility, recognition and a sense of accomplishment of the task, a healthy non-physical work environment, such as supportive policies, nurturing supervisors, pleasant co-workers, and a comfortable work environment.

Another opinion says that compensation is the entire remuneration received by employees for carrying out their work, and then the company replaces it in the form of money, allowances, or awards which aim to motivate employees to participate in company growth and development activities and also build employee commitment (Tj Winoto and Paulus, 2015). Compensation has an important role in retaining competent employees. The technique used by many company managers in general to build employee retention is to compensate or reward employees after each employee's evaluation of their performance.

\section{Supervisor Support}

Supervisor support is the level where direct supervisor appreciates the contribution of the employees they lead and also pay attention to their welfare. A great supervisor must be able to motivate all team members and ensure they do a good job for achieving company goals. Ahmad, Bibi and Majid (2018), also explained that if employees receive adequate support from their supervisor, they will show positive behavior towards the organization. Support from direct supervisors plays an important role in creating employee retention. Loyalty to the company will be greater when supervisors and employees under them share a positive and strong relationship with each other.

These organizations will be more likely to retain employees over long periods of time. Employees become closer and involved in their duties if there is open communication and develop employees' competencies and skills. If there is no process of transparency and understanding between supervisor and subordinates, this can result in pressure and ultimately cause stress for employees and lead to decreased efficiency and performance. In order to improve the effectiveness and competence of employees in a company, it is very important to have mutually supportive relationships between supervisors and subordinates.

\section{Job Satisfaction}


The work performed by an employee is not only limited to routine daily activities, but it also requires interaction with co-workers or leaders, and must adapt to the environment and working conditions. Therefore, the measure of job satisfaction for each person can be different. The definition of job satisfaction according to Hasibuan (2012) is a pleasant emotional attitude and loves his job. This attitude is reflected in work morale, discipline and work performance. Job satisfaction can be enjoyed at work, outside work, and a combination of inside and outside work.

Job satisfaction is one of the factors that can affect employee performance and ultimately can affect organizational effectiveness. In addition, job satisfaction for an employee is not only given through salary or incentives, but employees also need motivation, recognition and appreciation from their supervisor for their work, a work situation that is not monotonous and the opportunity to be creative and take the initiative in work. Many people argue that one way to increase productivity is to increase job satisfaction.

There are 4 factors that affect job satisfaction according to Soetrisno (2015):

1. Psychological factors, which are factors related to an employee's psyche, which include interests, talents, attitudes, and peace at work.

2. Social factors, are various factors related to social interactions between employees and employee interactions with supervisor.

3. Physical factors, are factors that have a relationship with the physical condition of employees which include health conditions, age, type of work, temperature conditions, space, time management, work equipment, lighting conditions, air exchange, and so on. 4. Financial factors, are factors related to employee security and welfare, for example the system and amount of salary, various kinds of benefits, promotions, facilities, social security and so on.

\section{Employee Retention}

Retaining employees in the long term, especially the best employees is a challenge faced by any company or organization. Employee retention is a phenomenon where employees choose to stay with their current company and do not actively seek out other job prospects. According to Ragupathi (2013), the definition of employee retention is one of the techniques used by management to be able to keep employees in an organization for quite a long time. In every company there are employees with very diverse behaviors, but employees are the most valuable asset for any company or organization.

Every company wants their employees to work for a long term. This is because the company has invested both money and time in the employee recruitment process. Replacing old employees with new ones will increase operating costs because it creates new employee training costs. The activities of a company are closely related to its human resources. The company's operational activities can run well if the company is able to manage and utilize its human resources optimally.

One of the efforts taken by the company in retaining its employees is by increasing employee satisfaction in carry out their duties. By creating employee welfare and job satisfaction, they will be able to work well with co-workers, be fully involved in work and more responsible. If employees see that the company where they work is growing rapidly, then they will be motivated not to searching for another job because with the development of the company their future will be more secure. 


\section{RESEARCH METHODS}

The population in this study were all employees at PT Pradu. The study population was 55 employees and the sampling technique used in this study was total sampling, that is a sampling technique where the number was the same as the population (Sugiyono, 2017). The reason for using this total sampling technique is because the number of samples less than 100 people so that the entire population of 55 employees at PT Pradu is used as the research sample. The data source used in this research is primary data that we get directly from the source. Data collection techniques used were through questionnaires, interviews, and literature study. Processing or analysis of statistical data will use Smart PLS (Partial Least Square) version 3.2.7.

According to Tecoalu et al. (2020), research using Smart PLS includes several types of measurements:

1. Outer Model (Measurement Model) is a model that connects indicators with latent variables (consisting of convergent validity, discriminant validity, and reliability tests).

2. Inner Model (Structural Model) is a model that connects between latent variables (consisting of the $\mathrm{R}$ square and $\mathrm{Q}$ square tests).

3. Hypothesis testing. The criteria for testing the hypothesis are accepted is if the $t$ statistics value $>1.96$ ( $t$-table value with alpha 5\%) and the $P$-value $<0.05$.

The conceptual framework of this research can be visualized as shown below:

\section{Figure 1.1 Conceptual Framework}

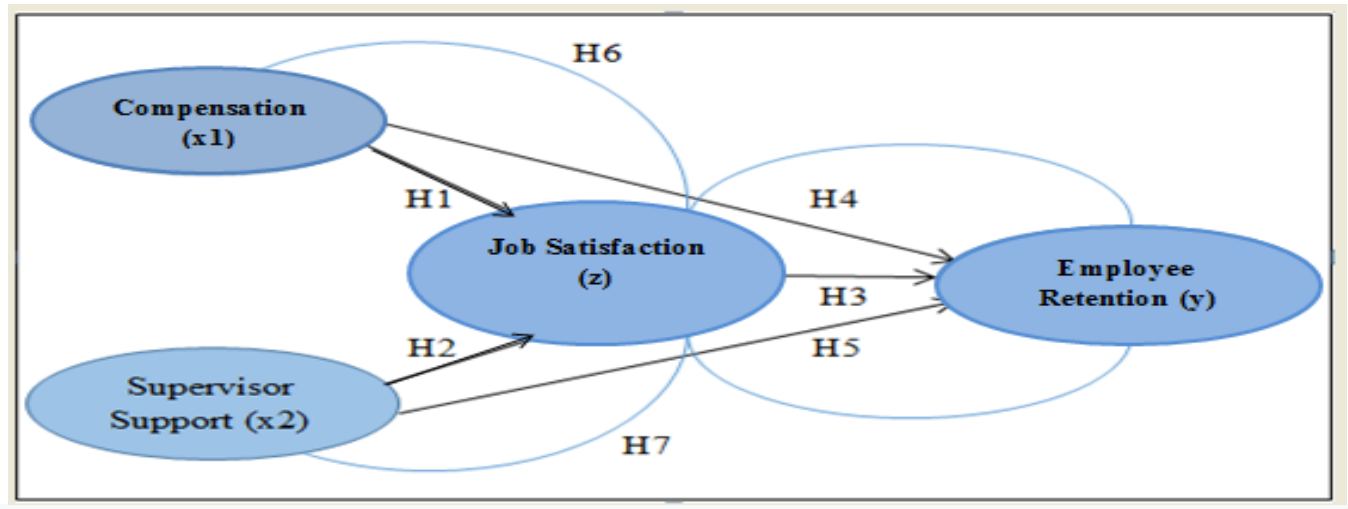

The hypothesis in this study are:

H1: Compensation has an effect to Job Satisfaction.

H2: Supervisor Support has an effect to Job Satisfaction.

H3: Job Satisfaction has an effect to Employee Retention.

H4: Compensation has an effect to Employee Retention.

H5: Supervisor Support has an effect to Employee Retention.

H6: Job satisfaction mediates the effect of Compensation to Employee Retention.

H7: Job satisfaction mediates the effect of Supervisor Support to Employee Retention. 
Convergent validity can be tested through the loading factor parameter and the average variance extracted (AVE) value. A measurement is said to have convergent validity if the loading factor value is $>0.7$ and the AVE value is $>0.5$.

Table 3.1 Value of Cross Loadings

\begin{tabular}{|c|c|c|c|c|}
\hline & $\begin{array}{c}\text { Job } \\
\text { Satisfaction }\end{array}$ & Compensation & $\begin{array}{c}\text { Employee } \\
\text { Retention }\end{array}$ & $\begin{array}{c}\text { Supervisor } \\
\text { Support }\end{array}$ \\
\hline KK1 & 0,770 & 0,358 & 0,369 & 0,794 \\
\hline KK2 & 0,715 & 0,397 & 0,421 & 0,420 \\
\hline KK3 & 0,737 & 0,504 & 0,397 & 0,574 \\
\hline KK4 & 0,738 & 0,580 & 0,512 & 0,496 \\
\hline KK5 & 0,734 & 0,679 & 0,401 & 0,413 \\
\hline KP1 & 0,556 & 0,779 & 0,349 & 0,425 \\
\hline KP2 & 0,364 & 0,718 & 0,331 & 0,206 \\
\hline KP3 & 0,498 & 0,758 & 0,306 & 0,229 \\
\hline KP4 & 0,640 & 0,815 & 0,308 & 0,458 \\
\hline RK1 & 0,460 & 0,438 & 0,712 & 0,485 \\
\hline RK2 & 0,460 & 0,321 & 0,807 & 0,320 \\
\hline RK3 & 0,379 & 0,324 & 0,738 & 0,306 \\
\hline RK4 & 0,512 & 0,302 & 0,831 & 0,286 \\
\hline RK5 & 0,317 & 0,174 & 0,730 & 0,180 \\
\hline SS1 & 0,601 & 0,287 & 0,236 & 0,832 \\
\hline SS2 & 0,665 & 0,383 & 0,291 & 0,851 \\
\hline SS3 & 0,712 & 0,489 & 0,519 & 0,892 \\
\hline SS4 & 0,568 & 0,306 & 0,407 & 0,878 \\
\hline SS5 & 0,572 & 0,298 & 0,379 & 0,865 \\
\hline SS6 & 0,592 & 0,466 & 0,266 & 0,735 \\
\hline
\end{tabular}

Source: SmartPLS Data Processing, 2020

From this table we can conclude that each indicator value of every variable is valid because it has a value $>0.7$.

Table 3.2. Average Variance Extracted (AVE)

\begin{tabular}{|c|c|}
\hline Variable & Average Variance Extracted (AVE) \\
\hline Compensation & 0,590 \\
\hline Supervisor Support & 0,712 \\
\hline Job Satisfaction & 0,546 \\
\hline Employee Retention & 0,585 \\
\hline
\end{tabular}

From table 3.2 above, it can be seen that the average value of the extract variant from each variable is $>0.5$ so it is considered valid.

\section{Table 3.3. Discriminant Validity}


PRIMANOMICS : JURNAL EKONOMI DAN BISNIS - VOL. 19. NO. 1 (2021)

Versi Online Tersedia di : https://jurnal.ubd.ac.id/index.php/ds | 1412-632X (Cetak) | 2614-6789 (Online) |

\begin{tabular}{|c|c|c|c|c|}
\hline & $\begin{array}{c}\text { Job } \\
\text { Satisfaction }\end{array}$ & Compensation & $\begin{array}{c}\text { Employee } \\
\text { Retention }\end{array}$ & $\begin{array}{c}\text { Supervisor } \\
\text { Support }\end{array}$ \\
\hline Job Satisfaction & 0,739 & & & \\
\hline Compensation & 0,684 & 0,768 & & \\
\hline Employee Retention & 0,569 & 0,419 & 0,765 & \\
\hline Supervisor Support & 0,737 & 0,445 & 0,424 & 0,844 \\
\hline
\end{tabular}

Source: SmartPLS Data Processing, 2020

A research model has discriminant validity if the AVE for each latent variable must be higher than the highest $\mathrm{r}^{2}$ value with all other latent variables (Fornell-Lacker criterion). In addition, the parameter value of cross loading is $>0.7$. This requirement has been fulfilled based on table 3.3 so it is considered valid.

\section{Reliability Test}

Reliability test is done to verify whether a measurement result is relatively consistent or reliable if the measurement is repeated two or more times at different times. The reliability test in SmartPLS can use 2 methods, namely Cronbach's Alpha and composite reliability. A variable is said to be reliable if the Cronbach's Alpha value and also the composite reliability value is $>0.7$.

Table 3.4. Cronbach's Alpha dan Composite Reliability

\begin{tabular}{|c|c|c|}
\hline & Cronbach's Alpha & Composite Reliability \\
\hline Job Satisfaction & 0,792 & 0,857 \\
\hline Compensation & 0,770 & 0,852 \\
\hline Employee Retention & 0,823 & 0,875 \\
\hline Supervisor Support & 0,918 & 0,937 \\
\hline
\end{tabular}

\section{Source: SmartPLS Data Processing, 2020}

From the table above, it can be seen that the composite reliability and Cronbach's Alpha values of all variables are $>0.7$ so we can conclude that all variables in this study are reliable and each indicator of these variables can be trusted to represent each variable. 
Table 3.5 R-square

\begin{tabular}{|c|c|c|}
\hline & R Square & R Square Adjusted \\
\hline Job Satisfaction & 0,701 & 0,690 \\
\hline Employee Retention & 0,325 & 0,286 \\
\hline
\end{tabular}

\section{Source: SmartPLS Data Processing, 2020}

Based on the R-square table above, we can conclude that:

1. The ability of compensation variable and the supervisor support variable in explaining the job satisfaction variable is 0.701 or $70 \%$, and the remaining $30 \%$ is explained by other factors outside of this research variable.

2. The ability of compensation variable, supervisor support, and job satisfaction in explaining the employee retention variable is 0.325 or $32.5 \%$, and the remaining $67.5 \%$ is explained by other factors outside this research variable.

\section{Q-Square Test}

Calculation of the Q-square value can be seen using the following formula:

Q-square : 1 - [(1-R21) X (1-R22)]

$$
\begin{aligned}
& : 1-[(1-0,701) X(1-0,325)] \\
& : 1-(0,299 \times 0,325) \\
& : 1-0,097175
\end{aligned}
$$

: 0,902825

Based on the results of the above calculations, we can see that the amount of diversity in research data can be explained by this study by $90 \%$ and the remaining $10 \%$ explained by other factors outside the study. Thus the research model already has a goodness of fit, which means that the predictive ability of the model is very good.

\section{Research Hypothesis}

In this study, there are 7 hypotheses with the following analysis:

- Hypothesis 1: Compensation has an effect to job satisfaction. This hypothesis is accepted because the t-statistics value of 4.629 is greater than 1.96 and the $P$ value of 0.000 is smaller than 0.05 . This is supported by previous research conducted by Parimita et al (2018) and also Akmal and Tamini (2015) which states that there is a positive influence between compensation and job satisfaction.

- Hypothesis 2: Supervisor support has an effect to job satisfaction. This hypothesis is accepted because the t-statistics value of 6.122 is greater than 1.96 and the $P$ value of 0.000 is smaller than 0.05 . This statement is in accordance with previous research by Firdausi (2018) and Astuti (2019) which states that supervisor support has a positive influence on work-life balance and job satisfaction.

- Hypothesis 3: Job satisfaction has an influence on employee retention. This hypothesis is accepted because the t-statistics value of 2.331 is greater than 1.96 and the P value of 0.020 is smaller than 0.05 . This is in accordance with previous research by Lisdayanti, et al. (2015) and also according to Motlou et al. (2016) that job satisfaction has a positive effect on employee retention.

- Hypothesis 4: Compensation has an effect to employee retention. This hypothesis was rejected because the t-statistics value of 0.297 is smaller than 1.96 and the $\mathrm{P}$ value of 
0.766 is greater than 0.05 . The results of this study are different from previous studies according to Pradipta and Suwandana (2019), also Putra and Rahyuda (2016) which state that compensation has a positive effect on employee retention.

- Hypothesis 5: Supervisor support has an influence on employee retention. This hypothesis is rejected because the t-statistics value of 0.097 is smaller than 1.96 and the $\mathrm{P}$ value of 0.923 is greater than 0.05 . This result is different with previous research by Nasir and Mahmood (2018) and also by Zafar (2015) which states that there is a positive influence between supervisor support on employee retention.

- Hypothesis 6: Job Satisfaction mediates the effect of Compensation to Employee Retention. This hypothesis is accepted because the t-statistics value of 2.040 is greater than 1.96 and the $P$ value of 0.042 is smaller than 0.05 . This is in line with previous research conducted by Astuti (2014) and Syahreza et al. (2017) which states that there is a positive effect of compensation on employee retention through job satisfaction.

- Hypothesis 7: Job Satisfaction mediates the influence of Supervisors to Employee Retention. This hypothesis is accepted because the t-statistic value of 2.194 is greater than 1.96 and the P value of 0.029 is smaller than 0.05 . This is in accordance with the results of previous research which states that a smooth communication process occurs and there is a mutual understanding between managers and employees, so it can involve employees by encouraging greater commitment to the organization through better job satisfaction (Nasir and Mahmood, 2016) .

\section{CONCLUSIONS}

Based on the results of data analysis and also the results of testing on all variables (compensation, supervisor support, job satisfaction, and employee retention) to employees at PT Pradu, we can conclude the following:

1. Compensation has an effect to employee job satisfaction at PT Pradu. This means that the more competitive the types of compensation provided will increase employee job satisfaction.

2. Supervisor support has an effect to job satisfaction. With good guidance, support and cooperation from direct supervisors, it will increase enthusiasm and motivation in daily work so as to create job satisfaction for employees at PT Pradu.

3. Job satisfaction has an effect to employee retention. This means that if PT the employees at PT Pradu feel satisfaction in their work, the employee retention rate will increase so that it has a big impact on the achievement of company goals.

4. Compensation has no effect on employee retention at PT Pradu. This means that even though the compensation is already competitive, it does not directly affect the employee's desire to stay in the company for a long period of time. There are other factors that directly influence employee retention beyond compensation.

5. Supervisor support has no effect on employee retention at PT Pradu. This means that even though the direct supervisor has supported and guided his employees well, it has no direct effect on increasing employee retention.

6. Job satisfaction can mediate the effect of compensation on employee retention at PT Pradu. This means that the giving of appropriate compensation can increase employee retention if through employee job satisfaction that is formed first. 
7. Job satisfaction can mediate the influence of supervisor support on employee retention at PT Pradu. This means that the support of direct supervisors can increase employee retention if it is through job satisfaction first.

\section{REFERENCES}

Ahmad, Ashfaq, Palwasha Bibi, and Abdul Halim Majid. 2018. The Impact of Training and Development and Supervisors Support on Employees Retention in Academic Institutions in Pakistan: The Moderating Role of the Work Environment. Gadjah Mada International Journal of Business, Vol. 20, No. 1 (January-April): 113-131.

Akmal, Akhwanul dan Ihda Tamini. 2015. Pengaruh Kompensasi Terhadap Kepuasan Kerja Karyawan Gayamakmur Mobil Medan. Jurnal Bisnis Administrasi, Vol. 04, No. 02: 59-68.

Astuti, Ambar Kusuma. 2019. Peranan Dukungan Supervisor Pada Keseimbangan Kehidupan Kerja Dan Kepuasan Karyawan. Jurnal Riset Manajemen dan Bisnis, Vol.14, No.1 (Juni): 43-56.

Astuti, Diah Puji. 2014. Pengaruh Kompensasi Terhadap Retensi Karyawan Melalui Kepuasan Kerja dan Komitmen Afektif Pada Beberapa Rumah Sakit di DKI Jakarta. Jurnal Manajemen dan Pemasaran Jasa, Vol.7, No.1: 199-217.

Badriyah, Mila. 2015. Manajemen Sumber daya Manusia. Bandung: CV Pustaka Setia.

Firdausi, Annas. 2018. Pengaruh Supervisi Dan Kepercayaan Diri Terhadap Kepuasan Kerja Guru SMKN Di Jakarta Timur. Jurnal Susunan Artikel Pendidikan, Vol.2 No.3, 270-278.

Handaru. 2013. Pengaruh Lingkungan Kerja, Kompensasi dan Komitmen Organisasi Terhadap Kepuasan Kerja Karyawan Di RS. X. Jurnal Riset Manajemen Sains Indonesia. 4(1), pp: 117-135.

Hasibuan, Malayu. 2012. Manajemen Sumber Daya Manusia. Jakarta: Bumi Aksara.

Lisdayanti, dkk. 2015. Pengaruh Kepuasan Kerja Terhadap Retensi Karyawan Pada PT Bumi Sari Prima Pematangsiantar. Maker: Jurnal Manajemen. Vol.1, No.1 (Juni): 3038.

Motlou, Reuben., Singh, Suveera., and Karodia, Anis Mahomed. (2016). An Evaluation of The Impact of Job Satisfaction On Employee Retention At

Lonmin Rowland Shaft North West Province. Arabian Journal of Business And Management Review, 5(10), pp: 15-49.

Mudayen. 2010. Pengaruh Kompensasi, Pengembangan Karir, Lingkungan Dan Pengalaman Terhadap Motivasi Dan Prestasi Kerja. Jurnal Penelitian. 13(2), pp: 169-198.

Nasir, Shuana Zafar dan Mahmood, Nasir. 2016. HRM Practices for Employee Retention: An Analysis of Pakistani Companies. European Journal of Business and Management. Vol. 8 No.30, pages 96-104.

Nasir, Shuana Zafar dan Mahmood, Nasir. 2018. A Study of Effect of Employee Retention on Organizational Competence. International Journal of Academic Research in Business and Social Sciences. Vol. 8, No. 4 (April), Pg. 408-415.

Parimita, Widya, Siti Khoiriyah, dan Agung Wahyu Handaru. 2018. Pengaruh Motivasi Kerja Dan Kompensasi Terhadap Kepuasan Kerja Pada Karyawan PT Tridaya Eramina Bahari. Jurnal Riset Manajemen Sains Indonesia, Vol.9 No. 1, 125-144. 
Putra, Ida Bagus G.S. dan Agoes Ganesha Rahyuda. 2016. Pengaruh Kompensasi, Lingkungan Kerja Dan Perceived Organizational Support (POS) Terhadap Retensi Karyawan. E-Jurnal Manajemen Unud, Vol. 5, No. 2: 810-837.

Pradipta, Putu S. Aditya dan I Gusti Made Suwandana. 2019. Pengaruh Kompensasi, Kepuasan Kerja Dan Pengembangan Karir Terhadap Retensi Karyawan. E-Jurnal Manajemen, Vol. 8, No. 4, pages 2409-2438.

Ragupathi. 2013. The Employee Retention Practices of MNC'S in Hyderabad. Research Journal of Management Sciences. 2(4), pp: 21-24.

Sugiyono. 2017. Metode Penelitian Kuantitatif, Kualitatif, dan RED. Bandung: Alfabeta.

Sutrisno, Edy. 2015. Manajemen Sumber Daya Manusia. Jakarta : Kencana Prenada Media.

Syahreza, D. S., Lumbanraja, P., Dalimunthe, R. F., \& Absah, Y. 2017. Compensation, Employee Performance, and Mediating Role of Retention: A Study of Differential Semantic Scales. European Research Studies Journal, Vol.20, pages 151-159.

Tecoalu, Melitina, Fidela Sadikin, dan Eka Desy. 2020. The Effect of Servant Leadership and Work Engagement on Organizational Citizenship Behavior Mediated by Organizational Commitment on Volunteers in Abbalove Ministries Church. Advances in Economics, Business and Management Research, Vol. 145, pages 146-152.

Tj Winoto, Hery dan Erwin Paulus. 2015. Pengaruh Kompensasi dan Kepuasan Kerja Terhadap Turnover Intention Karyawan (Studi Kasus pada PT Multi Abadi Sejahtera). Jurnal Ilmiah Manajemen Bisnis, Vol. 15 No. 2, pages 81-97.

Zafar, Anam. 2015. The Consequences of Supervisory Support on Employee Retention in Rawalpindi, Pakistan. International Knowledge Sharing Platform Journals \& Books Hosting, Vol.5 No.13, pages 23-30. 